\title{
HUBUNGAN KETENTUAN ANTARA PELAYANAN KELUARGA BERENCANA PASCASALIN DAN PASCAKEGUGURAN BERDASAR PERATURAN KEPALA BKKBN NOMOR 146/HK-10/B5/2009 DENGAN ASAS KEMANUSIAAN
}

\author{
Rima Nopiantini, Agnes Widanti dan Hadi Susiarno \\ Rima.nopiantini@gmail.com \\ Magister Hukum Kesehatan \\ Universitas Katolik Soegijapranata Semarang
}

\begin{abstract}
ABSTRAK
Pelayanan Keluarga Berencana merupakan bagian terpadu dalam program pembangunan dan kesehatan. Salah satu Pelayanan ini diatur dalam Peraturan Kepala BKKBN Nomor 146/HK10/B5/2009 yang perlu dipandang dari asas kemanusiaanya.

Penelitian ini menggunakan Metode Penelitian Deskriptif dengan pendekatan Metode Penelitian Hukum Normatif. Penelitian ini hanya menggunakan data sekunder dalam bentuk Bahan Pustaka berupa buku dan jurnal. Bahan Pustaka yang digunakan berupa bahan hukum, yakni bahan hukum primer, sekunder dan tersier.

Ketentuan Pelayanan Keluarga pascasalin dan pascakeguguran diatur oleh Peraturan Kepala BKKBN Nomor 146/HK-10/B5/2009 tentang pedoman pelayanan keluarga berencana pascasalin dan pascakeguguran untuk kelangsungan hidup ibu, bayi dan anak. Asas Kemanusiaan yaitu asas yang berisi nilai-nilai kemanusiaan, nilai keadilan yang harus diwujudkan dalam kehidupan masyarakat sehingga setiap manusia mendapatkan pengakuan, perlakukan dan penghargaan sesuai harkat kemanusiaan..

Hasil penelitian hubungan antara Peraturan Kepala BKKBN Nomor 146/HK-10/B5/2009 tentang pedoman pelayanan keluarga berencana pascasalin dan pascakeguguran untuk kelangsungan hidup ibu, bayi dan anak dimaksudkan untuk memberikan perlindungan dan keamanan dalam pelayanan kepada pasien pascasalin dan pascakeguguran dengan asas kemanusiaan yaitu jika ditentukan Peraturan Kepala BKKBN Nomor 146/HK-10/B5/2009 tentang pedoman pelayanan keluarga berencana pascasalin dan pascakeguguran untuk kelangsungan hidup ibu, bayi dan anak maka tidak dapat memenuhi asas Kemanusiaan.
\end{abstract}

Kata kunci : Pelayanan Keluarga Berencana pascasalin dan pascakeguguran, asas kemanusiaan 


\section{PENDAHULUAN}

\section{Latar Belakang Masalah}

Indonesia seperti yang kita ketahui merupakan negara yang termasuk memiliki kepadatan penduduk terbanyak di dunia. Hal ini disebabkan salah satunya adalah karena negara Indonesia memiliki tingkat kelahiran yang tinggi. Kepadatan penduduk tersebut tentu saja menjadi suatu masalah untuk negara Indonesia yang perlu diperhatikan oleh pemerintah sehingga banyak upaya pengendalian pertumbuhan penduduk melalui suatu program. Salah satu program yang dipilih oleh pemerintah Indonesia untuk mengurangi kepadatan penduduk tersebut dengan cara melakukan program Keluarga Berencana atau dikenal dengan singkatan KB.

Program Keluarga Berencana merupakan bagian terpadu dalam program pembangunan nasional yang bertujuan untuk mewujudkan penduduk tumbuh seimbang agar kesejahteraan ekonomi, spiritual, dan sosial budaya penduduk Indonesia dapat tercapai dengan Total Fertility Rate (TFR) 2,2 dan program KB di Indonesia telah berhasil menurunkan angka kelahiran total (TFR) dari 5,6 anak per wanita usia subur pada awal tahun 70an menjadi sekitar 2,3-2,6 anak per wanita usia subur pada tahun 2007.

Walaupun demikian, hal tersebut tidak menyelesaiakan masalah begitu saja karena berdasarkan sensus Badan Pusat Statistik (BPS) tahun 2010, jumlah penduduk Indonesia berjumlah 237,641,326 jiwa yang mengalami peningkatan sebesar 5,32\% dari tahun $2007 .{ }^{3}$

AKI dan AKB di Indonesia masih tinggi dibandingkan dengan negara ASEAN lainnya. Menurut data Survei Demografi Kesehatan Indonesia (SDKI) 2007, AKI di Indonesia adalah 228 per 100.000 kelahiran hidup, AKB 34 per 1.000 Walaupun menunjukkan penurunan, angka ini masih jauh dari target tahun 2015 yaitu 102 kematian per 100.000 kelahiran hidup. Kemudian, Hasil Survey Demografi dan Kesehatan 2012 menunjukkan AKB mencapai 32 per 1.000 kelahiran hidup, sementara target Indonesia sebesar 23 per 1.000 kelahiran hidup. Angka kematian pada bayi usia di bawah 28 hari masih cukup tinggi, jumlahnya mencapai 50 persen dari angka kasus kematian bayi secara keseluruhan dan umumnya disebabkan karena kesulitan bernapas saat lahir (asfiksia), infeksi, dan komplikasi lahir dini serta berat badan lahir rendah. Sulitnya menurunkan AKB disebabkan antara lain belum meratanya persebaran tenaga kesehatan, terutama untuk wilayah Indonesia bagian timur, belum memadainya fasilitas kesehatan dan tidak adanya akses yang cukup baik bagi warga terhadat pelayanan kesehatan. ${ }^{4}$

Dengan Laju Pertumbuhan Penduduk (LPP) sebesar 1,28\% yang diperkirakan jumlah kelahiran di Indonesia sebesar 5 Juta jiwa per tahun dan perkiraan angka keguguran sebesar 3,5 juta per tahun. Sedangkan perkiraan persalinan yang terjadi di Rumah Sakit 20\%,Bidan praktek swasta 30\% dan Puskesmas/Bidan Pedesaan 50\%.

Pasangan Usia Subur merupakan target pelayanan kontrasepsi yang utama. Pasangan Usia Subur merupakan pasangan suami istri yang usia istrinya antara 15-49 tahun. Walaupun demikian, jika melihat pertimbangan fisik, kesehatan reproduksi dan mental usia terbaik untuk hamil dan melahirkan adalah 20-35 tahun. Sehingga pasangan usia subur yang berada di bawah 20 tahun dan berada di atas 35 tahun mempunyai risiko tinggi untuk melahirkan. Wanita hamil kurang dari 20 tahun dapat merugikan kesehatan ibu maupun pertumbuhan dan perkembangan janin karena belum matangnya alat reproduksi untuk hamil dan sering mengalami komplikasi kehamilan, persalinan, dan komplikasi keguguran. Sedangkan hamil di atas usia 35 tahun

\footnotetext{
1 Badan Pusat Statistik dan Macro Internasional.2008. Survey Demografi dan Kesehatan Indonesia 2007.Calverton.Mryland USA. BPS. Dan Macro Internasional

2 BKKBN. 2012. Evaluasi Pelaksanaa Program Kependudukan dan KB tahun 2011. Jakarta.

3 Badan Pusat Statistik. 2013. Laporan data Bulanan Sosial Ekonomi.Jakarta

4 lbid
} 
mempunyai risiko keguguran, karena semakin lanjut usia menurunnya kualitas sel telur dan ovum dan meningkatnya risiko kejadian kelainan kromosom. Oleh karena itu, 4 Terlalu yaitu terlalu muda (kurang dari 20 tahun), terlalu tua (lebih dari 35 tahun), terlalu dekat (kurang dari 1 tahun) dan terlalu banyak anak (lebih dari 2 anak), khususnya batas usia Pasangan Usia Subur harus menjadi perhatian dalam merencanakan kehamilan dan penggunaan alat kontrasepsi. ${ }^{5}$

Selain itu yang menjadi bahan perhatian yaitu jumlah Pasangan Usia Subur yang ingin menunda kehamilan atau tidak ingin punya anak lagi namun tidak menggunakan kontrasepsi (unmet need) mencapai angka 9\% menurut SDKI 2007 dan 12,1\% menurut Mini Survey 2009. Unmet Need tersebut berdasarkan data SDKI 2007 disebabkan antara lain karena belum optimalnya konseling sebagai sarana komunikasi informasi dan edukasi pelayanan keluarga berencana (KB), ketakutan akan efek samping, serta Kematian ibu juga diakibatkan beberapa faktor risiko keterlambatan (Tiga Terlambat), diantaranya terlambat dalam pemeriksaan kehamilan, terlambat dalam memperoleh pelayanan persalinan dari tenaga kesehatan, dan terlambat sampai di fasilitas kesehatan pada saat dalam keadaan emergensi. Salah satu upaya pencegahannya adalah melakukan persalinan yang ditolong oleh tenaga kesehatan di fasilitas kesehatan.

Dalam Undang-Undang Nomor 36 tahun 2009 tentang Kesehatan, pada pasal 5 ayat (1) menegaskan bahwa setiap orang mempunyai hak yang sama dalam memperoleh akses atas sumber daya di bidang kesehatan. Selanjutnya pada ayat (2) ditegaskan bahwa setiap orang mempunyai hak dalam memperoleh pelayanan kesehatan yang aman, bermutu, dan terjangkau. Kemudian pada ayat (3) bahwa setiap orang berhak secara mandiri dan bertanggung jawab menentukan sendiri pelayanan kesehatan yang diperlukan bagi dirinya. Selanjutnya pada pasal 6 ditegaskan bahwa setiap orang berhak mendapatkan lingkungan yang sehat bagi pencapaian derajat kesehatan. Untuk menjamin terpenuhinya hak hidup sehat bagi seluruh penduduk termasuk penduduk miskin dan tidak mampu, pemerintah bertanggung jawab atas ketersediaan sumber daya di bidang kesehatan yang adil dan merata bagi seluruh masyarakat untuk memperoleh derajat kesehatan yang setinggi-tingginya.

Mengingat masih tingginya jumlah kelahiran per tahun, tingginya Angka Kematian ibu dan bayi, masih banyaknya kehamilan dan persalinan yang tidak aman maka diperlukan upaya untuk mengendalikan kelahiran melalui perencanaan keluarga dengan menggunakan kontrasepsi khususnya untuk pascasalin dan pascakegugran.

Dengan tingginya angka kematian ibu dan bayi, adanya angka keguguran yang tinggi, dan program-program yang telah dilaksanakan untuk meningkatkan pelayanan keluarga berencana pasca persalinan dan Pascakeguguran telah diterbitkan Peraturan Kepala BKKBN Nomor 146/HK10/B5/2009 tentang pedoman pelayanan keluarga berencana pascasalinan dan pascakeguguran untuk kelangsungan hidup ibu, bayi dan anak. Maka perlu melihat sejauh mana peraturan ini telah diterapkan dalam pelaksanaan program tersebut berjalan dengan baik atau tidak. Karena pelayanan Pelayanan Keluarga Berencana saat ini masih menjadi fokus pemerintah Republik Indonesia berkaitan dengan kekhawatiran adanya ledakan penduduk di masa depan. ${ }^{2}$

Program keluarga berencana merupakan hak perempuan dan dilaksanakan atas dasar sukarela serta tidak bertentangan dengan agama, kepercayaan dan moral Pancasila. Selain itu, program keluarga berencana merupakan bagian yang tidak dapat terpisahkan dari kesehatan reproduksi. Hak reproduksi sebagaimana terdapat dalam ICPD 1994 :

Hak reproduksi pada dasarnya adalah hak perempuan dan laki-laki untuk memperoleh informasi dan memperoleh akses terhadap cara-cara keluarga berencana atau metode-metode pengaturan fertilitas yang aman, efektif, terjangkau, dan dapat diterima sesuai pilihan mereka

5 Direktorat Kelangsungan Hidup Ibu, Bayi, dan Anak BKKBN, Ingin memiliki Kesehatan Reproduksi Prima hindari 4 Terlalu, Jakarta 2007 
dan hak untuk memperoleh pelayanan pemeliharaan kesehatan yang tepat yang memungkinkan perempuan dengan selamat menjalani kehamilan dan melahirkan anak sehat. ${ }^{6,7}$

Hak reproduksi merupakan bagian dari Hak Asasi Manusia (HAM). Hak asasi di dalam kesehatan reproduksi merupakan bagian dari asas kemanusiaan (humanisme) yang senantiasa berkembang dinamis pada nilai, norma, keyakinan dan pengertiannya.

Asas kemanusiaan mengakui akan persamaan derajat, persamaan hak dan kewajiban antara sesama manusia, pengembangan sikap tenggang rasa dan tepa selira serta menjunjung tinggi nilai kemanusiaan. $^{8}$

Menurut Undang- undang Nomor 39 tahun 1999 tentang Hak Asasi Manusia menyatakan bahwa hak asasi manusia adalah seperangkat hak yang melekat pada hakikat dan keberadaan manusia sebagai makhluk Tuhan Yang Maha Esa dan merupakan anugrah-Nya yang wajib dihormati, dijunjung tinggi dan dilindingi oleh negara hukum, pemerintahan, dan setiap orang demi kehormatan serta serta perlindungan harkat dan martabat manusia.

Hak Asasi Manusia harus dijunjung tinggi secara kodrati dan tidak terpisahkan dari manusia, yang harus dilindungi, dihormati dan ditegakkan demi martabat kemanusiaan, kesejahteraan, kebahagiaan, kecerdasan dan keadilan.

Pengembangan manusia seutuhnya sebagai hakikat pembangunan nasional dicapai dengan berhasilnya salah satunya sektor yaitu pembangunan kesehatan. Sebagai generasi penerus yang akan melanjutkan pembangunan bangsa menuju masyarakat sejahtera, adil dan makmur, proses pertumbuhan penduduk harus dipantau dan dikendalikan salah satunya dengan pengadaan program Keluarga Berencana (KB)

Dengan tingginya angka kematian ibu dan bayi, adanya angka keguguran yang tinggi, dan program-program yang telah dilaksanakan untuk meningkatkan pelayanan keluarga berencana pasca persalinan dan Pascakeguguran telah diterbitkan Peraturan Kepala BKKBN Nomor 146/HK10/B5/2009 tentang pedoman pelayanan keluarga berencana pascasalinan dan pascakeguguran untuk kelangsungan hidup ibu, bayi dan anak. Maka perlu melihat sejauh mana peraturan ini telah diterapkan dalam pelaksanaannya apakah sudah diterapkan atau tidak dan sejauh mana jika dilihat dari asas kemanusiaan.

Berdasarkan latar belakang di atas, penulis tertarik untuk meneliti lebih lanjut mengenai "Hubungan antara Ketentuan Pelayanan Keluarga Berencana Pascasalin dan Pascakeguguran Berdasar Peraturan Kepala BKKBN Nomor 146/HK-10/B5/2009 dengan Asas Kemanusiaan”

\section{Perumusan Masalah}

Permasalahan dalam penelitian ini yaitu :

1. Bagaimana identifikasi ketentuan tentang pelayanan keluarga berencana pascasalin dan pascakeguguran?

2. Bagaimana identifikasi hubungan ketentuan pelayanan keluarga berencana pascasalin dan pascakeguguran Peraturan Kepala BKKBN Nomor 146/HK-10/B5/2009 dengan asas kemanusiaan?

6 Sri Yuliani, 2006, Perempuan dan Kebijakan Pengendalian Kelahiran, Jurnal Penduduk, LIPI.go.id

7 Kartono Mohamad,2007,Kesehatan Reproduksi sebagai hak,Jakarta: Yayasan Jurnal Perempuan, Hal 9

8 Kementrian Pendidikan dan Kebudayaan, Materi Ajar Mata Kuliah Pancasila, hal 36 


\section{Metode Penelitian}

Metode penelitian yang digunakan dalam penelitian ini adalah metode penelitian yuridis normatif. Penelitian yuridis normatif adalah suatu cara meneliti dalam penelitian hukum yang dialakukan dengan cara meneliti bahan pustaka atau data sekunder saja dan dengan menggunakan metode berfikir. analisis data penelitian ini adalah metode kualitatif normatif, metode ini akan menganalisis data-data sekunder dalam bentuk kalimat yang konsisten, logis, efektif dan sistematis.Jenis data yang digunakan dalam penelitian hukum normatif ini data sekunder yaitu dari penelitian kepustakaan dan dokumentasi hasil penelitian yang tersedia dalam bentuk buku.

\section{PEMBAHASAN}

\section{Ketentuan Pelayanan Keluarga Berencana Pascasalin dan Pascakeguguran.}

Ketentuan dari Kepala BKKBN Nomor 146/HK-10/B5/2009 Pelayanan Keluarga Berencana Pasca Persalinan dan Pasca Keguguran merupakan suatu ketentuan yang menjadi pedoman program yang bertujuan dalam pemberian pelayanan yang aman dan sehat dalam pengaturan jarak kehamilan, jarak kelahiran dan menghindari kehamilan yang tidak diinginkan sehingga setiap keluarga dapat merencanakan kehamilan yang aman, sehat dan sekaligus sebagai promosi Kelangsungan Hidup Ibu, Bayi dan Anak. Pasca Persalinan dan Pasca Keguguran merupakan waktu yang tepat bagi ibu untuk menggunakan salah satu alat kontrasepsi sesuai dengan pilihan rasional, efektif dan efisien sehingga dapat meningkatkan taraf kesehatan ibu, bayi dan anak yang lebih baik.

Sesuai dengan hasil Konferensi Internasional Population and Developtment (ICPD ) di Kairo tahun 1994, serta visi dan misi BKKBN Pendekatan Keluarga Berencana (KB) ke arah pendekatan kesehatan reproduksi. Program KB dan Kesehatan Reproduksi saat ini tidak hanya ditujukan untuk penurunan angka kelahiran namun dikaitkan pula pada dengan tujuan untuk pemenuhan hak-hak reproduksi, promosi, pencegahan, penanganan masalah-masalah kesehatan reproduksi dan seksual serta menjaga kesehatan dan kesejahteraan ibu,bayi dan anak.

Target pemerintah Indonesia mengenai kesehatan reproduksi yang akan dicapai sampai pada tahun 2015 yang terangkum dalam indikasi keberhasilan program Millenium Development Goals (MDGs) adalah cakupan layanan KB pada Pasangan Usia Subur 70\%, penurunan prevalensi kehamilan " 4 terlalu” mencapai 50\%, penurunan kejadian komplikasi KB serta penurunan angka drop out penggunaan alat kontrasepsi.

Program keluarga berencana untuk mempertahan kualitas hidupnya membutuhkan pelayanan yang aman dan sehat kemudian dengan Pertimbangan bahwa keluarga berencana dan keluarga sejahtera dalam program keluarga berencana nasional menjadi kewenangan pemerintah, untuk melaksanakan ketentuan pasal 9 peraturan pemerintah nomor 38 tahun 2007 tentang pembagian urusan pemerintahan perlu menetapkan norma, standar, prosedur, dan kriteria, dan mengingat undang-undang nomor 10 tahun 1992 tentang perkembangan kependudukan dan pembangunan keluarga sejahtera, kemudian mengingat peraturan pemerintah nomor 21 tahun 1994 tentang penyelenggaraan pembangunan keluarga sejahtera maka perlu ditetapannya ketentuan mengenai pedoman pelayanan keluarga berencana pascapersalinan dan pascakeguguran untuk kelangsungan hidup ibu, bayi dan anak,

Pelaksanaan program keluarga berencana yang dijalankan diantaranya pada keluarga berencana pascasalin dan pascakeguguran yang menekankan pada pelayanan penggunaan alat kontrasepsi diantaranya menggunakan KB. Jika dilihat dari hasil evalusi BKKBN mengenai pelaksanaan program kependudukan dan Keluarga Berencana tahun 2011 diantaranya mengenai program pengaturan kehamilan, program ketahanan dan pemberdayaan keluarga yang 
menunjukan bahwa pencapaian pelayanan peserta KB belum memenuhi target sasaran, karena dari yang ditargetkan sebanyak 92.297 peserta hanya sebanyak 75.000 peserta.

Berdasarkan hasil penilitian mengenai upaya meningkatkan pemakaian alat kontrasepsi (keluarga Berencana) pasca persalinan dan pascakeguguran menyatakan bahwa Trend pelayanan KB di Rumah Sakit Pemerintah dan Swasta menunjukan adanya penurunan kualitas pelayanan KB baik di rumah sakit pemerintah maupun swasta. Rendahnya pelayanan KB di Rumah Sakit pemerintah maupun swasta disebabkan terbatasnya tenaga yang kompeten dalam pelayanan KB, biaya untuk kontrasepsi yang disediakan pemerintah melalui BKKBN lebih rendah dari pada perturan yang ditetapkan yang berlaku di rumah sakit. Terbatasnya adanya tenaga pencatatan dan pelaporan hasil pelayanan KB serta pelaksanaan pencatatan dan pelaporan yang belum optimal.

Sehingga dapat disimpulkan bahwa pelaksanaan dari Ketentuan dari Kepala BKKBN Nomor 146/HK-10/B5/2009 Pelayanan Keluarga Berencana Pasca Persalinan dan Pasca Keguguran yang bertujuan memberikan pedoman pada pelayanan program pelayanan KB belum berjalan dengan baik karena masih ditemukan penurunan kualitas pelayanan KB baik di rumah sakit pemerintah maupun swasta.

\section{Hubungan antara Ketentuan Pelayanan Keluarga Berencana Pascasalin dan Pascakeguguran dengan Asas Kemanusiaan}

Dengan adanya Ketentuan mengenai pedoman pelayanan keluarga berencana pascapersalinan dan pascakeguguran yang memberikan acuan dan pedoman pelayanan yang sehat dan aman seharusnya program keluarga berencana dapat berjalan dengan baik tetapi Angka kematian ibu dan bayi di Indonesia masih tinggi 228 per 100.000 kelahiran hidup AKI di Indonesia adalah AKB mencapai 32 per 1.000 kelahiran hidup dan masyarakat masih kurang memperhatikan $4 \mathrm{~T}$ yaitu terlalu muda ( kurang dari 20 tahun), terlalu tua (lebih dari 35 tahun), terlalu dekat ( kurang dari 1 tahun) dan terlalu banyak anak (lebih dari 2 anak). ${ }^{9}$

Berdasarkan data dari WHO beberapa penelitian dilakukan. Penelitian di beberapa fasilitas kesehatan di Indonesia memperkirakan sekitar 25-60\% kejadian aborsi adalah aborsi disengaja (induced abortion). Data Depkes RI tahun 2000 menunjukkan keguguran di Indonesia sekitar 17,8\% di 27 provinsi. Survei Kesehatan Rumah Tangga (SKRT) 1995 menyebutkan bahwa aborsi berkontribusi 11,1\% terhadap kematian ibu di Indonesia.

Berdasarkan status sosial ekonomi, unmet need pada golongan menengah dan golongan teratas masih cukup tinggi yaitu 8,5 persen pada golongan menengah dan 8,2 persen pada golongan teratas.

Wanita memiliki hak untuk menentukan kapan, seperti apa, mengapa, dengan siapa, dan bagaimana mengungkapkan seksualitasnya. Semua wanita, tanpa memandang umur, status kawin dan kondisi sosial lain memiliki hak atas informasi dan pelayanan yang diperlukan untuk menjalankan hak-hak dan tanggung jawab reproduksinya pria juga memiliki tanggung jawab personal dan sosial atas tingkah laku seksual dan fertilitasnya, dan atas dampak tingkah laku mereka pada kesehatan serta kesejahteraan pasangan dan anak-anak.

Hubungan seksual dan hubungan sosial antara wanita dan pria harus dilaksanakan melalui prinsip kesetaraan, keadilan, tanpa paksaan, saling hormat, dan tanggung jawab hak-hak dasar seksual dan reproduksi wanita tidak dapat dianggap kurang penting (berlawanan dengan kehendak wanita tersebut) bila dibandingkan dengan kepentingan pasangan, anggota-anggota keluarga, kelompok-kelompok etnis, lembaga-lembaga agama, petugas kesehatan, peneliti, pengambil keputusan, negara maupun pihak-pihak lain. Atas dasar itulah maka sudah saatnya kita meningkatkan partisipasi pria dalam KB dan Kesehatan Reproduksi, supaya wanita tidak menjadi

9 Badan Pusat statistik. Survey Demografi dan Kesehatan Indonesia 2007 
objek lagi dalam urusan KB dan Kesehatan Reproduksi. Disamping itu supaya wanita memiliki kesetaraaan dan keadilan serta berbagi tanggung jawab dengan pasangannya dalam urusan KB dan Kesehatan Reproduksi.

Namun pada kenyataanya masih jauh dari harapan, apabila melihat keadaan di lapangan banyak program keluarga berencana tanpa disadari dalam pemberian pelayanan mengesampingkan nilai kemanusiaan dan hak asasi manusia, karena banyak peserta KB mengikuti KB bukan atas dasar pilihan dan keputusannya tetapi atas dasar dorongan dari pihak lain.

Dengan adanya Peraturan Kepala BKKBN Nomor 146/HK-10/B5/2009 mengenai pedoman pelayanan keluarga berencana pascapersalinan dan pascakeguguran untuk kelangsungan hidup ibu, bayi dan anak dimaksudkan untuk memeberikan acuan bagi pemerintahan daerah provinsi, kabupaten, kota dalam melaksanakan kebijakan, program dan kegiatan pelayanan keluarga berencana pascapersalinan dan pascakeguuran dengan melakukan perencanaan, pelaksanaan, pemantauan, dan evaluasi, pelaporan, pendanaan dan pengawasaan. Ketentuan ini dalam penerapan pelayanan keluarga berencana pascapersalinan dan pascakeguguran belum berjalan dengan baik.

Berdasarkan Undang-undang RI nomor 52 tahun 2009 tentang perkembangan kependudukan dan pembangunan keluarga pasal 1 menyatakan bahwa keluarga berencana adalah mengatur kelahiran anak, jarak, dan usia ideal melahirkan, mengatur kehamilan melalui promosi, perlindungan, dan bantuan sesuai dengan hak reproduksi untuk mewujudkan keluarga yang berkualitas. Sedangkan dengan ketentuan dalam memberikan pelayanan terhadap pasien pascapersalinan dan pascakeguguran pada kenyataannya angka kelahiran masih tinggi dilihat dari pertumbuhan penduduk di Indonesia masih mengalami peningkatan sebesar 5,32\%. ${ }^{10}$

Selain itu dalam Undang-undang nomor 36 tentang Kesehatan tahun 2009 antara lain mengatur hak reproduksi dan keluarga berencana (KB), dalam pasal 71, 72, 73, 74, 78. Pasal 72 (b) menejelaskan bahwa menentukan kehidupan reproduksinya dan bebas dari diskriminasi, paksaaan, dan atau kekerasan yang menghormati nilai-nilai luhur yang tidak merendahkan martabat manusia sesuai dengan norma agama. Dalam pasal 73 menjelaskan bahwa pemerintah wajib menjamin ketersediaan sarana informasi dan sarana pelayanan kesehatan reproduksi yang aman, bermutu, dan terjangkau masyarakat, termasuk keluarga berencana. Sedangakan dalam pasal 78 menjelaskan bahwa pemerintah bertanggungjawab dan menjamin ketersediaan tenaga, fasilitas pelayanan, alat dan obat dalam memeberikan pelayanan keluarga berencana yang aman, bermutu, dan terjangkau oleh masyarakat.

Salah satunya asas Kemanusiaan adalah bahwa setiap materi muatan dalam suatu peraturan perundang-undangan harus mencerminkan perlindungan dan pengayoman hak-hak asasi manusia serta harkat dan martabat setiap warga Negara dan penduduk Indonesia secara proposional. Dalam menjalankan kehidupan bermasyarakat setiap manusia mempunyai hak-hak dasar sebagai manusia yang sudah ada sejak lahir yang harus dihormati dan dihargai oleh individu lainnya.

Dalam undang-undang Republik Indonesia nomor 29 tahun 2004 tentang praktik kedokteran, pasal 2 menjelaskan bahwa praktik kedokteran harus memberikan perlakuan yang sama dengan tidak membeda-bedakan suku, bangsa, agama, status sosial dan ras.

Pada sila kedua, kemanusiaan yang adil dan beradab. Manusia menghendaki terjadinya keseimbangan, keselarasan, keharmonisan, berkesinambungan dalam mencapai ketahanan tubuh, terampil, sehat jasmania dan rohaniah serta berbudi pekerti luhur dalam kehidupan manusia untuk mencapai kemanusiaan yang bersifat persamaan derajat, hak, dan kewajiban

10 Badan pusat Statistik, 2013, Laporan data Bulanan Sosial ekonomi, Jakarta 
tanpa membedaan suku, keturunan, agama, kepercayaan, dan kedudukan sosial. Sehingga setiap warga Negara di Indonesia mempunya kedudukan yang sama, hak dan kewajiban yang sama, tidak boleh memaksakan kehendak kepada orang lain karena setiap individu di Indonesia mempunya suara untuk keputusannya sendiri selama tidak mengganggu orang lain. Perbedaan antara individu hanya menunjukan perbedaan antara tugas dan kewajiban yang harus dijalaninya dalam kehidupan sehari-hari sehingga untuk menengahkan antara hak dan kewajiban dibutuhkan hukum, dan Indonesia merupakan Negara hukum, Negara yang berdasarkan Undang-undang dasar, yang menghormati kebebasan dan hak manusia.

Apabila Hal tersebut apabila dikaitkan dengan Hak asasi manusia sudah melanggar hak asasinya karena klien tersebut tidak dapat menentukan keputusan untuk menentukan hak dalam ber KB dan menentukan hak reproduksinya, dan dilihat dari peraturan BKKBN Nomor 146/HK10/B5/2009 dengan memberikan acuan dan pedoman dalam pelayanan yang sehat dan aman terdapat pada pasal 2 dan 3 ,masih ditemukan tingginya angka kematian, kelahiran,dan penurunan pelayanan KB baik pelayanan pemerintah maupun swasta.

Setelah dilakukan analisis kualitattif di atas, antara tinjauan dari ketentuan pelayanan keluarga berencana pascapersalinan dan pascakeguguran dengan tinjauan mengenai Asas Kemanusiaan dapat dirumuskan jawaban sementara yaitu jika ditentukan mengenai pelayanan keluarga pascapersalinan dan pascakeguguran maka tidak dapat memenuhi Asas Kemanusiaan.

\section{PENUTUP}

\section{Simpulan}

Berdasarkan hasil penelitian dan pembahasan di atas, maka dapat dapat ditarik kesimpulan:

1. Pelaksanaan dari Ketentuan dari Kepala BKKBN Nomor 146/HK-10/B5/2009 mengenai pedoman Pelayanan Keluarga Berencana Pasca Persalinan dan Pasca Keguguran pada pelayanan program pelayanan KB belum berjalan dengan baik.

2. Peraturan Kepala BKKBN Nomor 146/HK-10/B5/2009 dengan memberikan acuan dan pedoman dalam pelayanan yang sehat dan aman terdapat pada pasal 2 dan 3 ,masih ditemukan tingginya angka kematian, kelahiran,dan penurunan pelayanan KB baik pelayanan pemerintah maupun swasta dan apabila dikaitkan dengan asas kemanusiaan dan Hak asasi manusia sudah melanggar hak asasinya karena klien tersebut tidak dapat menentukan keputusan untuk menentukan hak dalam ber KB dan menentukan hak reproduksinya, sehingga dapat disimpulkan bahwa jika ditentukan mengenai pelayanan keluarga pascapersalinan dan pascakeguguran maka tidak dapat memenuhi Asas Kemanusiaan.

\section{Saran}

Dari hasil penelitian dan kesimpulan dari tesis ini dapat dirumuskan beberapa saran sebagai berikut:

1. Para pemegang kebijakan di pusat

Dengan diterbitkannya Peraturan Kepala BKKBN Nomor 146/HK-10/B5/2009 tentang pedoman pelayanan keluarga berencana pasca persalinan dan pascakeguguran untuk kelangsungan hidup ibu,bayi dan pemerintah dapat merealisasikan dan pemantauan pemberi an pelayanan dijalankan secara berkesinambungan.

2. Kepada Pemerintah provinsi

Untuk menindaklanjuti peraturan yang dibuat oleh BKKBN maka pemerintah provinsi disarankan untuk membuat petunjuk teknis yang lebih jelas dan berkesnimbungan dari mulai perencanaan sampai evaluasi. 
3. Kepada pemerintah daerah

Disamping menjalankan kebijakan juga harus memantau pelaksanaan dengan baik sehingga apabila dengan adanya pedoman yang dibuat maka program yang dilaksanakan dapat berjalan dengan baik.

4. Peraturan yang dibuat belum seutuhnya menjaga hak-hak asasi manusia dan nilai kemanusiaan sehingga dalam memberikan pelayanan dan menjalankannya di lapangan harus tetap dapat menjaga hak-hak asasi manusia dan nilai kemanusiaan.

\section{DAFTAR PUSTAKA}

Badan Pusat Statistik dan Macro Internasional, 2008, Survey Demografi dan Kesehatan Indonesia 2007.Calverton, Mryland USA, BPS Dan Macro Internasional

Badan Pusat Statistik, 2013, Laporan data Bulanan Sosial Ekonomi, Jakarta

Badan Pusat statistik. Survey Demografi dan Kesehatan Indonesia 2007

BKKBN, 2012, Evaluasi Pelaksanaa Program Kependudukan dan KB tahun 2011, Jakarta.

Direktorat Kelangsungan Hidup Ibu, Bayi, dan Anak BKKBN, Ingin Memiliki Kesehatan Reproduksi Prima Hindari 4 Terlalu, Jakarta 2007

Kartono Mohamad, 2007, Kesehatan Reproduksi sebagai hak, Jakarta: Yayasan Jurnal Perempuan.

Kementrian Pendidikan dan Kebudayaan, Materi Ajar Mata Kuliah Pancasila

Sri Yuliani, 2006, Perempuan dan Kebijakan Pengendalian Kelahiran, Jurnal Penduduk, LIPI.go.id

\section{PERATURAN}

Peraturan Pemerintah Nomor 21 Tahun 1994 Tentang Penyelenggaraan Pembangunan Keluarga Sejahtera

Peraturan Pemerintah Nomor 38 Tahun 2007 tentang Pembagian Urusan Pemerintahan

Peraturan BKKBN Nomor 146/HK-10/B5/2009 mengenai pedoman Pelayanan Keluarga Berencana Pasca Persalinan dan Pasca Keguguran pada pelayanan program pelayanan KB

Undang-undang Nomor 10 Tahun 1992 tentang Perkembangan Kependudukan Dan Pembangunan Keluarga Sejahtera

Undang- undang Nomor 39 Tahun 1999 tentang Hak Asasi Manusia

Undang-undang Republik Indonesia nomor 29 tahun 2004 tentang praktik kedokteran

Undang-undang Nomor 36 Tahun 2009 tentang Kesehatan 